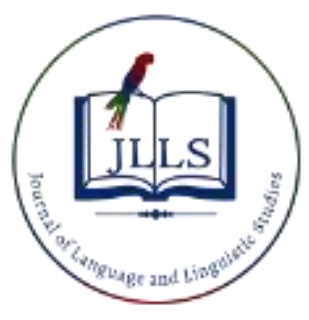

\title{
The effect of mobile-assisted language learning (MALL) on EFL learners' collocation learning
}

\section{APA Citation:}

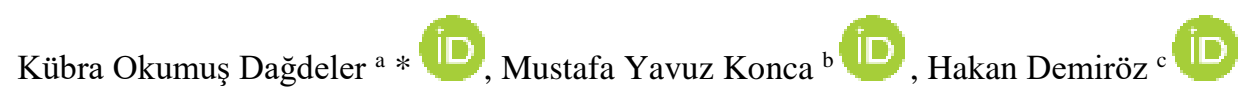

a Sivas Cumhuriyet University, Sivas 58000, Turkey

${ }^{b}$ A ğr İbrahim Çeçen University, Ağrı 04000, Turkey

${ }^{c}$ Sivas Cumhuriyet University, Sivas 58000, Turkey

Okumuş Dağdeler, K.; Konca, M. Y., \& Demiröz, H. (2020). The effect of mobile-assisted language learning (MALL) on EFL learners' collocation learning. Journal of Language and Linguistic Studies, 16(1), 489-509.

Submission Date: 31/12/2019

Acceptance Date: 14/02/2020

\begin{abstract}
The aim of this study was to identify the effectiveness of a mobile application in vocabulary knowledge improvement of English as a Foreign Language (EFL) learners. This study adopted a quasi-experimental research design consisting of an experimental and a control group with 73 participants studying at two state universities in Turkey. During the application that lasted for 14 weeks, the experimental group tried to learn 40 collocations via CollocatApp, while control group used worksheets. The data were gathered through Collocation Achievement Test (CAT) developed by the researchers and Vocabulary Knowledge Scale (VKS) (Wesche \& Paribakht, 1996). CAT was used for measuring receptive vocabulary knowledge of learners, and VKS was used for testing productive vocabulary knowledge. The findings showed that there was a significant difference between the experimental group and control group in terms of receptive vocabulary knowledge in the post-test. However, there was no difference between groups in retention tests. At the dimension of productive vocabulary knowledge, it was seen that there was no difference between the use of mobile applications and worksheets in terms of productive vocabulary knowledge. Thus, it was concluded that using mobile applications was an effective way of improving vocabulary knowledge receptively for only short-term memory.
\end{abstract}

(C) 2020 JLLS and the Authors - Published by JLLS.

Keywords: collocations, mobile-assisted language learning (MALL), vocabulary knowledge, EFL

\section{Introduction}

Becoming more and more popular, educational technology has affected education systems profoundly. Language learning and teaching get their share from this effect. Technology-based language learning has been one of the most popular areas in foreign language education research. The term computer-assisted language learning (CALL) may be the first concept that comes to mind while talking about technology in language education. CALL can briefly be defined as "the search for and study of applications of the computer in language teaching and learning" (Levy, 1997, p. 1). It was originally

\footnotetext{
${ }^{*}$ Kübra Okumuş Dağdeler. Tel.: +903462191010

E-mail address: kokumus@cumhuriyet.edu.tr
} 
developed at huge computers. Since computers were not tired and intolerant while presenting the same material continuously, CALL was seen as an excellent way of language learning (Huang, Huang, Huang, \& Lin, 2012). As Hubbard (2009) states, the knowledge and skills of CALL should be renewed continuously in order to keep up with the field, as technology develops quite fast. Thus, MALL and ubiquitous language learning become prominent due to technology that is rapidly changing and problems with CALL, such as the necessity of sitting in front of a computer at a specific time.

MALL is generally seen as the subset of CALL and mobile-learning (m-learning). However, Kukulska-Hulme and Shield (2008) state that MALL is different from CALL as it uses personal and portable devices that provide alternative ways of learning and "continuity or spontaneity of access and interaction across different contexts of use" (p. 273). MALL is applying m-learning to language learning. Rodríguez-Arancón, Arús and Calle-Martínez (2013) define MALL as "a teaching and learning methodology that uses mobile phones or other handheld devices with some form of wireless connectivity, such as phones, PDAs and tablets, among others" (p. 1190). O'Malley, Vavoula, Glew, Taylor and Sharples (2005) defined MALL as "any sort of learning that happens when the learner is not at a fixed, predetermined location, or learning that happens when the learner takes advantage of the learning opportunities offered by mobile technologies" (p. 6). Rahimi and Miri (2014) define MALL as any language learning activity occurring through mobile devices. MALL is an innovative and interesting way of learning a new language (Azar \& Nasiri, 2014). It is seen as a "convenient, practical and easy way of assisting ESL learners in enhancing their ESL learning" (Soleimani, İsmail \& Mustaffa, 2014, p. 457). MALL is seen an excellent solution to foreign language learning limitations related to time and place (Miangah \& Nezarat, 2012).

\subsection{Literature Review: Studies on the role of mobile technology in vocabulary learning}

When literature was reviewed, it was observed that the studies investigating the use of mobile devices in vocabulary learning could be classified as use of SMS - MMS (Alemi, Sarab, \& Lari, 2012; Çavuş \& Ibrahim, 2009; Hayati, Jalilifar, \& Mashhadi, 2013; Hu, 2013; Lu, 2008; Song \& Fox 2005; Zhang, Song, \& Burston, 2011), use of e-mail (Thornton \& Houser, 2005), use of some programs developed by individual researchers (Başoğlu \& Akdemir, 2010; Chen \& Chung, 2008; Stockwell, 2007; 2010) other mobile features (A ̆gca \& Özdemir, 2013; Liu \& Chen, 2014). These studies have generally suggested positive results. It was seen that experimental groups using mobile technology were more successful than control groups studying in a conventional way (Başoğlu \& Akdemir, 2010; Hayati et al, 2013; Liu \& Chen, 2014; Lu, 2008, Zhang et al., 2011). Related to the retention of the learned words some studies found that there was not a significant difference between groups ( $\mathrm{Lu}, 2008$; Zhang et al., 2011) while some others indicated that use of SMS provided retention of target words (Alemi, Sarab, \& Lari, 2012; Saran, Seferoglu, \& Cagiltay, 2012). As mobile devices have charming features, the learners can develop positive attitudes towards using them for learning vocabulary. The studies in the literature supported this notion (Başoğlu \& Akdemir, 2010; Hu, 2013; Zhang et al., 2011). Hu (2013) found that the students believed instant vocabulary text message system was to be a supporter of autonomous learning. Learners are able to exploit their fragmented time and to learn anywhere and are motivated thanks to mobile devices (Hu, 2013; Zhang et al., 2011). Despite the positive findings, Zhang et al. (2011) found that there were some problems that students reported. One of these problems was related to the nature of technology (e.g. phone's memory was not sufficient for many messages, phonetic symbols were not properly displayed). Another problem was that the students felt deconcentrated or distracted as they received continuous messages at the specific period of the day.

These studies indicate that vocabulary learning with mobile devices has been carried out with the help of SMS, e-mail, and some other specific programs developed by researchers. As for mobile applications that have attracted attention in the field of language learning in recent years, there are some 
studies that investigate the perception of language learners on use of mobile applications in language learning. For instance, Deng and Shao (2011) used a mobile application called Remword to investigate students' attitudes towards use of mobile applications in vocabulary building. They found that all students had positive opinion about the application. They concluded that some benefits of applications such as autonomy, flexibility, and low costs of internet access helped students learn vocabulary in a selfdirected way. Steel (2012) also searched the attitudes of learners towards use of mobile applications in language learning and concluded that mobile applications were useful as they provided practice in language anywhere and anytime. Moreover, some characteristics such as the convenience, portability and ease of use of mobile applications were the reasons for use. Nino (2015) also found that characteristics such as convenience, interactivity, immediate feedback and use of authentic resources were the advantages of the mobile applications. In both studies (Nino, 2015; Steel, 2012), it was found that vocabulary was the most frequently used part of language structures in mobile applications. In Rezaei, Mai and Pesaranghader's (2014) study, the learners believed that using mobile applications (Busuu and Interactive English) helped them feel more confident and had positive effect on their class participation. The researchers also gave a pretest and a posttest and observed that the learners were more successful in the posttest than the pretest. However, there was no control group in the study, so it cannot be reliably concluded that the difference was due to mobile applications. Wu (2015), using a Java application (Word Learning) for vocabulary learning, conducted an experimental study with college students. The results showed that the experimental group outperformed control group significantly in the posttest. Rahimi and Miri (2014) also integrated mobile dictionaries into the course in an experimental study. While the experimental group used mobile dictionaries, control group used printed dictionaries. At the posttest, there was a significant difference between two groups in the favor of the experimental group.

\subsection{Research Questions}

The previous studies show that language learners have positive attitudes towards the use of mobile devices in language learning (Ağca \& Özdemir, 2013; Lu, 2008; Polakova \& Klimova, 2019; Yurdagül $\&$ Öz, 2018). Mobile learning helps language learners get use of their fragmented time, provides audio and visual materials, and motivates them. However, it is open to debate if it has an effect on the success of learners. The SMS and e-mail based studies have found significant differences between learning vocabulary with traditional way and mobile learning. However, in the retention tests that are crucial in vocabulary learning, most of the studies have not observed any difference. Furthermore, there were some problems such as the finding of sending messages continuously was distracting for students in such studies. Lastly, the treatments in the studies were teacher-led while m-learning stresses the importance of learner-led learning. Thus, this study tried to use an application aiming to reduce these problems and teach collocations to college language learners. Thus, this study sought to find answers to the following research questions:

To what extent are mobile applications effective in improving prospective English language teachers' (hereafter PELT) vocabulary knowledge?

Are mobile applications effective in improving PELTs' receptive vocabulary knowledge?

Are mobile applications effective in improving PELTs' productive vocabulary knowledge?

\section{Method}

This study adopted a quantitative approach where a quasi-experimental design was used. Among the quasi-experimental designs, this study was non-equivalent groups pretest-posttest control group design 
in which "the researcher uses intact, already established groups of subjects, gives a pretest, administers the treatment condition to one group, and gives the posttest" (McMillan \& Schumacher, pp. 273-274). In this study, two preformed groups taken from two state universities were benefited. In order to hinder a possible interaction between groups which is a threat to reliability in experimental studies, university students from two different universities were selected. The implementation required a self-study approach so the researchers or practitioners conducted no treatments. Thus, there was not any problem related to selecting participants from two different universities. The experimental group and control group was assigned randomly. Students of ELT department in Cumhuriyet University formed the experimental group while the control group consisted of the students studying at the ELT department of Gazi University. The experimental group used a mobile application in order to learn new words while the control group was given worksheets. The content of the worksheets and mobile application were the same. The researchers developed both the app and the worksheets. The duration of the experiment was 14 weeks. At first, CAT and VKS were applied to both experimental and control groups as the pretests. Then, the treatment that lasted 9 weeks was given to the experimental group. Then the posttest was carried out. The delayed posttests were given three weeks after the learning period.

\subsection{Sample}

This study used a quasi-experimental design in which sampling is not fully random and randomization is done among the existing group. With random assignment, the experimental group was junior students receiving foreign language teacher education at one state university in Turkey and the control group consisted of junior students at another state university. As diffusion of treatment is an important threat to internal validity and a mobile application would easily spread among the participants, two different universities were preferred in order to hinder a possible interaction among them. The study took place in the spring semester of 2016/2017 academic year at Gazi University and Cumhuriyet University. The participants of this study were 73 university students. 36 of them were in the experimental group and 37 of them were in the control group.

\subsection{Instruments}

The data of the study were gathered through two different scales, Collocation Achievement Test (CAT) developed by the researchers and Vocabulary Knowledge Scale (VKS) that was originally developed by Wesche \& Paribakht (1996) and adapted based on the collocations used in the study. Schmitt (1998) states that it is difficult to measure both receptive and productive vocabulary knowledge by paying balanced attention to both of them in a scale due to the fact that "beginning levels of a scale usually focus on receptive knowledge and the more advanced levels on production" (p. 285). Due to this difficulty, two different scales, one of which focused on receptive vocabulary knowledge and the other one addressed productive vocabulary knowledge were used in this study.

\subsubsection{Collocation Achievement Test (CAT)}

To see if there was any significant difference between receptive vocabulary knowledge of experimental and control groups, an achievement test was developed by the researchers. Firstly, 42 multiple choice questions were written by the researchers. The questions were reviewed by 3 experts in the field. With the opinions of the experts, 2 questions were removed and 5 questions were revised. Then, the 40 questions were piloted with 63 university students who were similar to the target group. Based on the results, 8 items were removed as their item discrimination levels were under .19. Thus, the final version of the test consisted of 32 questions (see Appendix A). The item discrimination and difficulty levels of the remaining items were presented in Appendix A. The K21 reliability of the test was found to be 0.76 . 


\subsubsection{Vocabulary Knowledge Scale (VKS)}

VKS, developed by Wesche and Paribakht (1996), is now probably one of the best-known instruments assessing both receptive and productive vocabulary development (Bruton, 2009). Wesche and Paribakht (1996) state that VKS is a depth test while Laufer and Goldstein (2004) point out that VKS is "an indirect test of word meaning" (p. 403). VKS was used to check if the learners learned the meanings of target collocations in this study. Moreover, as VKS requires learners to use target words in a sentence it addresses the productive vocabulary knowledge as well. In this study, both receptive and productive vocabulary knowledge were assessed. While Collocation Achievement Test was used for receptive vocabulary knowledge (RVK), VKS was used with the aim of measuring PVK. VKS is a selfreport instrument in which learners assess themselves by giving a number between 1 and 5 . The meaning attributed to the numbers is as follows:

I don't remember having seen this word before.

I have seen this word before, but I don't know what it means.

I have seen this word before, and I think it means (synonym or translation).

I know this word it means (synonym or translation).

I can use this word in a sentence: . (Write a sentence)

As this scale has the characteristics of self-report, the researchers evaluated the answers of participants based on the VKS scoring of Wesche and Paribakht (1996). Inter-reliability of researchers' evaluations was checked by means of a second rater. Thus, two raters scored pretests and posttests of experimental and control groups based on the VKS scoring. After seeing that the reliability between raters was high, the analysis was done by taking averages of the raters. The VKS scoring proposed by Wesche and Paribakht (1996) is different from the scoring of the scale participants. If the participants know the meaning of the word and write a sentence, they mark "V". However, if the meaning is wrong the option of "II" is given by raters. If the word is not used semantically appropriate, then the option of "III" is given. If the sentence including target word is semantically appropriate but not grammatically appropriate, then "IV" is marked by raters. The option of "V" is given only when the meaning of the word is true and the sentence is both semantically and grammatically appropriate. The raters in this study made the evaluations based on this scoring. The concordance between the two raters were measured through Kappa analysis that was introduced by Cohen (1960) and correlation. The analysis showed that for the pretest, the concordance between Rater 1 and Rater 2 was found to be significant (Kappa ( $\kappa$ ) $=0,622 ; \mathrm{p}=0,000<0,05)$. The correlation between two raters in pretests was positive with the value of $98,6 \%(\mathrm{p}=0,000<0,05)$. For the posttest, the concordance between Rater 1 and Rater 2 was found to be significant (Kappa $(\kappa)=0,640 ; \mathrm{p}=0,000<0,05)$. The correlation between two raters in pretests was positive with the value of $99,9 \%(\mathrm{p}=0,000<0,05)$. 


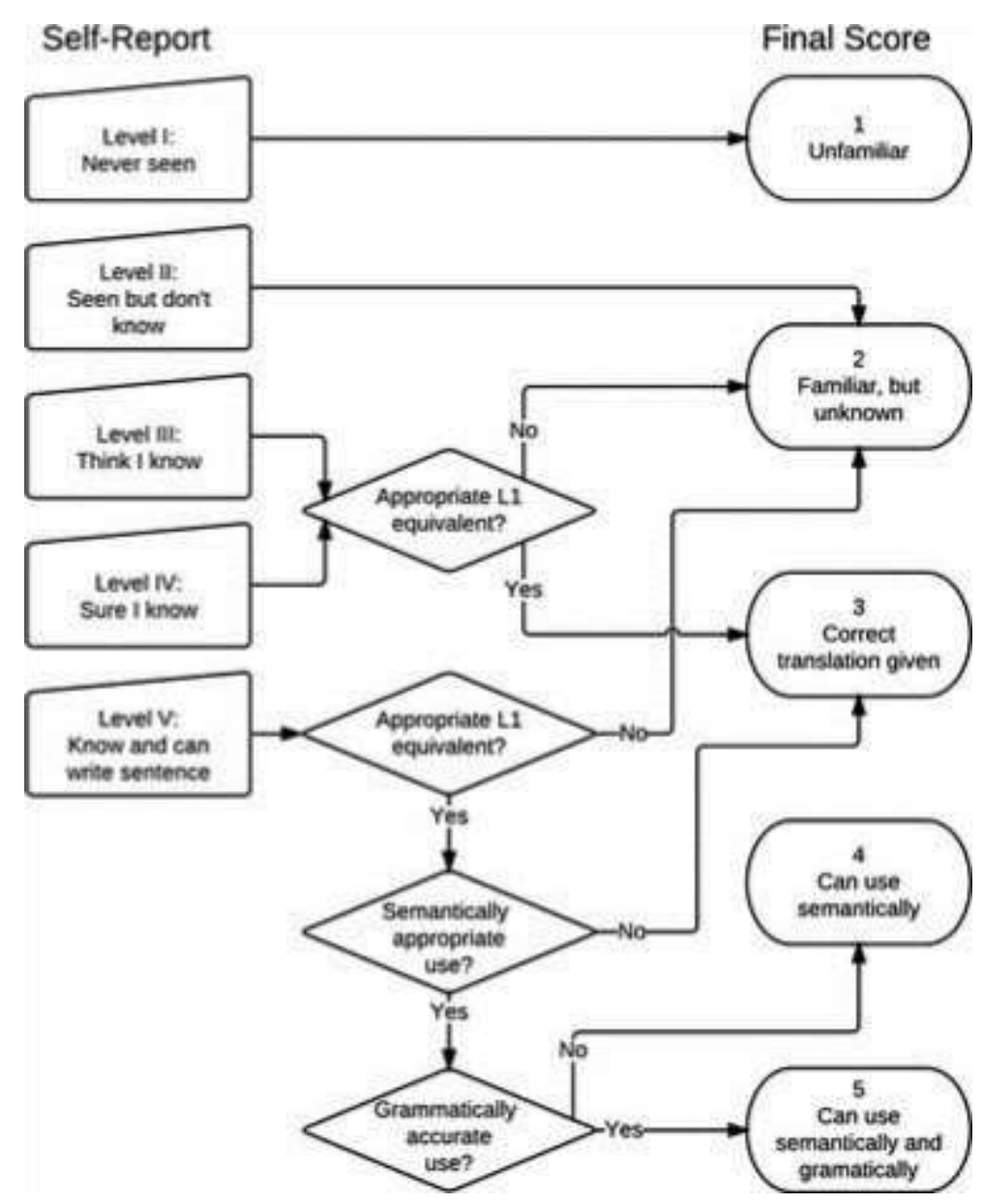

Figure 1. Flowchart of VKS scoring (Wesche and Paribakht, 1996)

\subsubsection{The corpus}

Before beginning the development of the mobile application, the collocations were chosen. While choosing the collocations, the collocations in O'Dell and McCarthy (2008) were used as a base by getting permission from Cambridge University Press. As known, there are seven grammatical types of collocations. Of these types, verb+noun, adjective+ noun and noun+noun collocations are the most frequently used ones. Thus, to ensure variety and teach the most needed types of collocation, collocations under these categories were included in the corpus. When forming the corpus, the frequency of the collocations was searched in Corpus of Contemporary American English (COCA) and collocations between the scores of 40-1011 were included. Highly frequent collocations were excluded lest the students would be familiar with them. The selected collocations and their frequency level (according to the COCA) were presented in Appendix B.

\subsubsection{The development of the CollocatApp for experimental group}

There are many mobile applications focusing on teaching vocabulary. Some of them are only dictionary and some include different activities or games that appeal to learners. However, the applications that focus only on collocations are limited. Besides, the existing ones are mostly dictionaries or include only matching activities. Thus, there was a need to develop a new application that would be used by the experimental group. After the corpus was determined, the design and content of the mobile application were prepared. The mobile application consisted of both a dictionary and activities. As both receptive and productive skills are important in vocabulary learning, activities based on these skills were 
developed. The mobile application consisted of five sections as 'Dictionary', 'True/False', 'Test', 'Writing', and 'Make Your Own Sentences' (see Figure 2).

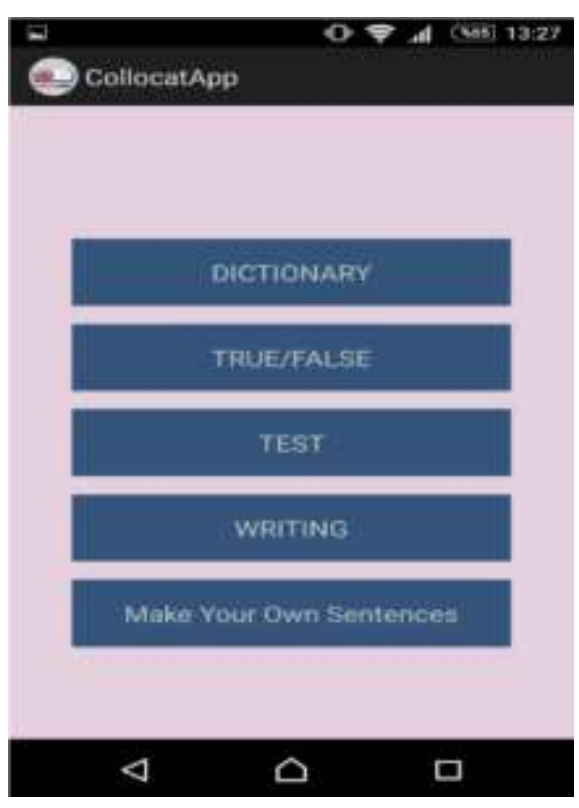

Figure 2. The activities

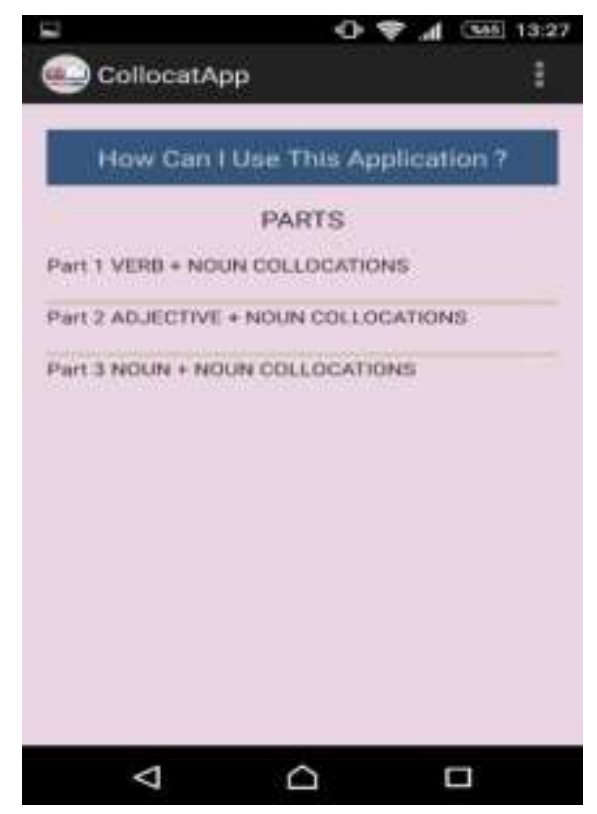

Figure 3. Main page of the app

The sections of the True/False and Dictionary focused on the meaning of collocations. These sections addressed receptive vocabulary learning as there was no production (see Figure 4 and 5).

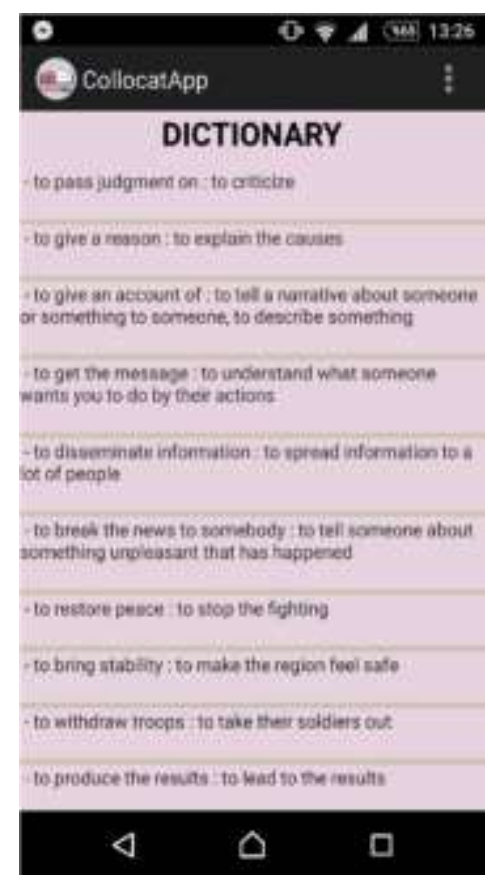

Figure 4. Dictionary

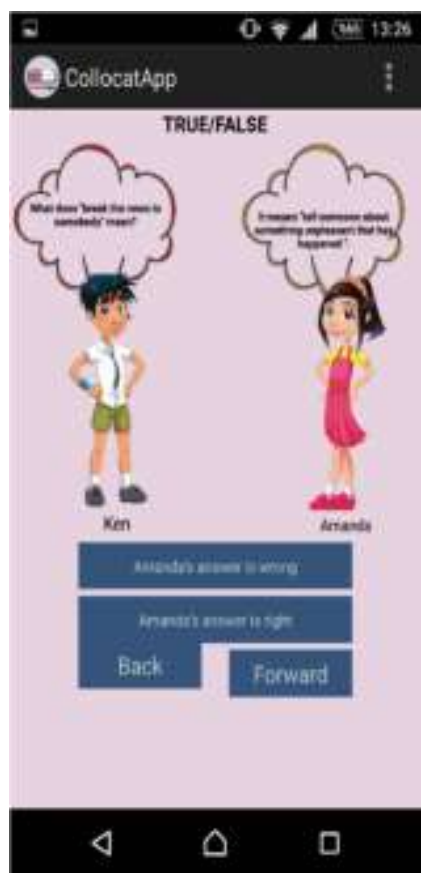

Figure 5. True/False

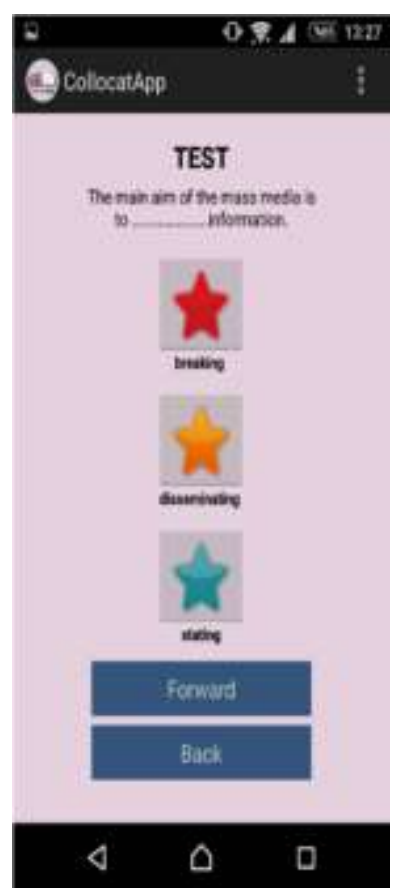

Figure 6.Test

The section of Writing focused on the sequence of the words. The sections of Test and Making Sentence focused on both meaning and sequence. While Test section addressed receptive vocabulary 
knowledge, Writing and Make Your Own Sentences helped students produce an outcome (see Figure 6, 7 and 8).

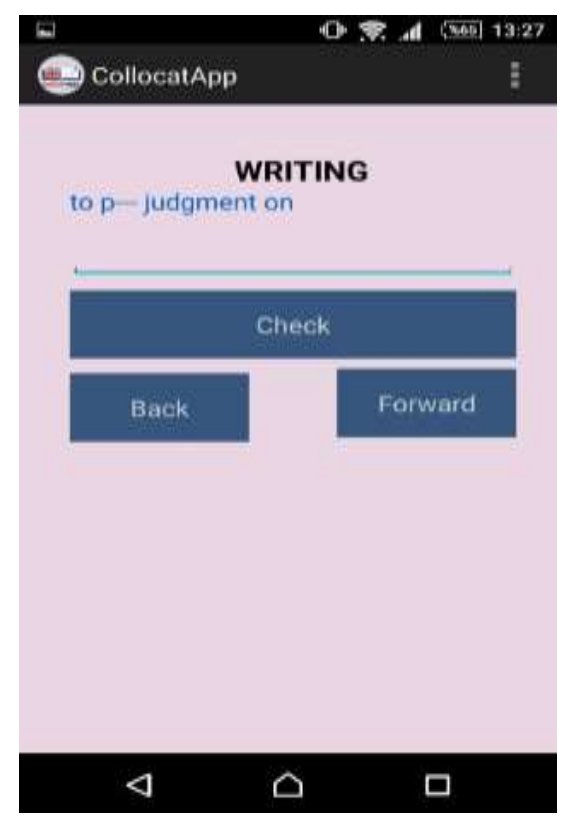

Figure 7. Writing

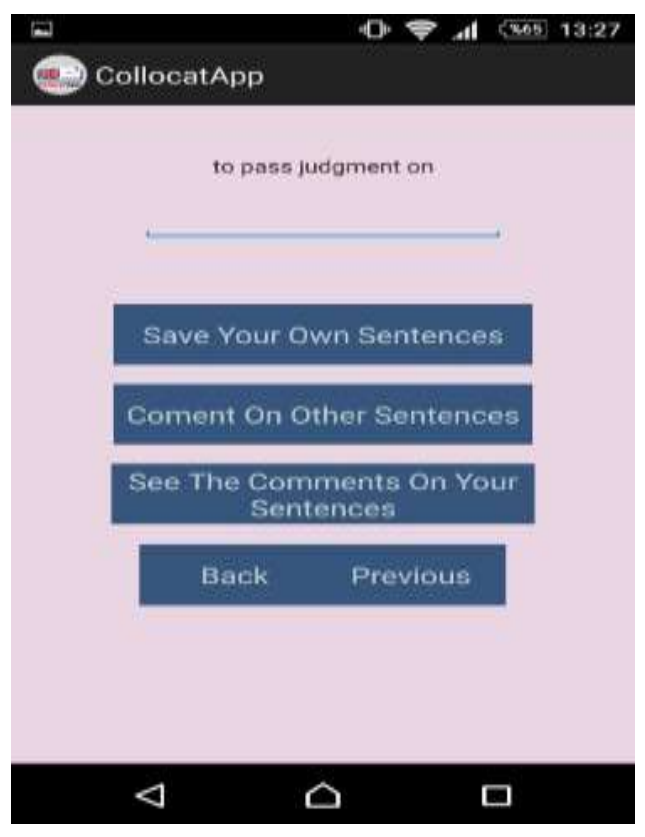

Figure 8. Make your own sentences

As error correction is important in education, when the answer was wrong the learner was directly directed to dictionary to see the right meaning and sequence of the collocation. Another important feature of the app was the interactivity. At the section of the making sentences, the learners both make their own sentences using the target words and give feedback on the sentences made by other users (see Figure 8). In order to provide this interactivity, user records were provided.

\subsubsection{Worksheets for the control group}

Worksheets were designed by the researchers for the control group. The content of the worksheet was the same with mobile application. The same collocations and questions were used in the worksheets. The activities were also the same except for the last activity that required interactivity. Since interactivity is a technical feature, it was not included in the worksheets. These worksheets were grouped into three as in CollocatApp. Thus, there were three worksheets, which were a) verb+ noun collocations, b) adjective+ noun collocations, and c) noun+noun collocations. All these worksheets were given together at the same time as in mobile application in which the learners were able to access all parts and activities at the same time.

\subsection{Data Analysis}

In order to analyze the quantitative data obtained from the scales, SSPS 21 program was used. Both descriptive and inferential statistical tests were calculated. Before analyzing the data, firstly the normality of scales was tested in order to decide which test would be used. The normality analysis indicated that CAT showed normal scatter whereas VKS results did not indicate normal scatter. Thus, parametric tests such as paired sample t-test, independent sample t-test and ANCOVA was used for analysing the data on CAT but nonparametric tests such as Wilcoxon signed and Man Whitney u tests were used for the data obtained through VKS. 


\section{Results}

The success of learners in learning collocation was measured with two scales that were VKS and CAT. The results of these two scales were analyzed independently and then the results were discussed in the Discussion part.

\subsection{Findings related to receptive vocabulary knowledge}

The data related to receptive vocabulary knowledge were obtained through CAT. The findings of this test were presented in this part.

\subsubsection{Paired sample t-test results for CAT}

In order to see if there was a difference between pre-test and post-test of groups, paired sample t-test was used. The findings were presented in Table 1.

Table 1. Paired Sample t-test Results for Experimental and Control Group in CAT

\begin{tabular}{llcccccc}
\hline Group & Test & N & $X$ & S & sd & t & P \\
\hline Experimental & Pretest & 33 & 15.15 & .096 & 32 & 3.154 & .009 \\
& Posttest & 33 & 28.31 & .320 & & & \\
& & & & & & & \\
\hline Control & Pretest & 36 & 26.94 & 2.61 & 35 & 2.009 & .052 \\
& Posttest & 36 & 25.16 & 4.51 & & &
\end{tabular}

According to Table 1, there was a significant difference $(t(32)=3.154, p<0.05)$ between the pretest scores $(X=15.15)$ and the posttest scores of the experimental group $(X=28.31)$. In other words, posttest scores were statistically higher than the pretest scores of this group. When the size of this effect was calculated, it was found that it was in high level $(\eta 2=0.77)$. Hence, it can be commented that use of mobile application was effective for learning collocations receptively. On the other hand, the difference between the scores of pretest $(X=26.94)$ and posttest of the control group $(X=25.16)$ was not significant $\left(t_{(35)}=2.009, p<0.05\right)$. In other words, use of worksheets for learning collocations did not improve receptive vocabulary knowledge of language learners.

\subsubsection{ANCOVA results for CAT}

Independent sample t-test was used in order to identify if there was a significant difference between the pretest scores of experimental and control group. The findings were presented below:

Table 2. Independent Sample t-test Results for Pretests in CAT

\begin{tabular}{llcllll}
\hline & $\mathbf{N}$ & $\bar{X}$ & $\mathbf{S}$ & sd & T & P \\
\hline Control G. & 36 & 26.67 & .247 & 75 & -3.017 & .000 \\
Experimental. & 33 & 15.15 & .096 & & & \\
\hline
\end{tabular}


The findings showed that there was a significant difference $(t(75)=-3.017, p<0.05)$ between the pretests of the control group $(X=26.67)$ and experimental group $(X=15.15)$. Due to a significant difference, ANCOVA was used as it eliminates the differences identified in the pretest scores of experimental and control group at the beginning of the treatment in experimental studies (Seçer, 2013). The posttest scores of experimental and control groups were compared with controlling the pretest scores of both groups through ANCOVA. The findings were shown in Table 3.

Table 3. Posttest Scores of Experimental and Control Groups

\begin{tabular}{llll}
\hline Group & N & Mean & Corrected Mean \\
\hline Control G. & 36 & 25.16 & 21.75 \\
Experimental & 33 & 28.31 & 32.65 \\
& & & \\
\hline
\end{tabular}

Table 3 shows that the uncontrolled mean scores of posttest were 25.16 for the control group and 28.31 for the experimental group. When the pretest scores were controlled, it was seen that there were changes in posttest scores. The controlled posttest mean score was 21.75 for the control group and 32.65 for the experimental group.

The results of ANCOVA were presented below.

Table 4. ANCOVA Results for Posttest Scores of Groups

\begin{tabular}{llllll}
\hline Source & Sum of squares & Sd & Mean square & F & P \\
\hline Pretest & .731 & 1 & .731 & -6.706 & .012 \\
Group & 1.655 & 1 & 1.655 & -15.179 & .000 \\
Error & 7.417 & 68 & .109 & & \\
Total (Corrected) & 9.121 & 70 & & & \\
& & & & & \\
\hline
\end{tabular}

Table 4 indicates that there was a significant difference between the posttest of both groups when the pretests were controlled $\left.\mathrm{F}_{(1-68)}=-15.179, \mathrm{p}<0.05\right)$. In other words, the posttest scores of the experimental group were found significantly higher than those of the control group. The size of this effect was found to be $\eta 2=0,18$.

\subsubsection{Independent sample t-test results for retention in CAT}

An independent sample t-test was conducted with the aim of identifying the difference between the posttests and delayed posttests of groups. Table 5 shows the results of this analysis. 
Table 5. Independent Sample t-test Results for Experimental Group for Retention

\begin{tabular}{llllllll}
\hline Group & Test & N & $X$ & S & sd & t & P \\
\hline Experimental & Posttest & 35 & 28.31 & .347 & 34 & 1.373 & .000 \\
& Delayed test & 35 & 21.02 & 1.092 & & & \\
& & & & & & & \\
\hline Control & Posttest & 36 & 25.16 & .708 & 35 & 1.344 & .000 \\
& Delayed test & 36 & 21.40 & .322 & & & \\
& & & & & & & \\
\hline
\end{tabular}

It was observed that there was a significant difference between the posttest mean scores $(X=28.31)$ and delayed test mean scores $(X=21.02)$. The effect size was found to be medium $(\eta 2=0.32)$. This shows that the collocations learned by students were mostly forgotten in three weeks. A similar result to the experimental group was observed in control group. Table 5 indicates that there was a significant difference between the posttest $(X=25.16)$ and delayed test $(X=21.40)$. The effect size was found to be small $(\eta 2=0.23)$.

\subsection{Findings related to productive vocabulary knowledge}

The data on PVK were obtained through VKS. The findings of this test are presented in this part. In order to see if there was any difference between the pretest and posttest scores of groups, Wilcoxon Signed Ranks test was carried out. The findings were presented below:

Table 6. Wilcoxon Signed Rank test results for VKS

\begin{tabular}{lllllll}
\hline Group & Test & N & Mean Ranks & Sum of Ranks & z & P \\
\hline Experimental & Pretest & 29 & 179.690 & 25.0 & -4.164 & .000 \\
& Posttest & 29 & 215.552 & 410.0 & & \\
& & & & & & \\
& & & & & & \\
\hline Control & Pretest & 29 & 183.516 & 324.50 & & \\
& Posttest & 29 & 196.807 & & &
\end{tabular}

The findings showed that the increase in the posttest scores was statistically significant $(p=.000<0.05)$. In other words, use of mobile application affected learners' productive vocabulary knowledge positively. However, as to the Wilcoxon test, there was no significant difference between pretest and posttest scores of the control group $(p=.058>0.05)$ meaning that use of worksheets did not improve learners' productive vocabulary knowledge.

\subsubsection{Mann-Whitney $U$ test results for VKS}

In order to see if there was any significant difference between the posttest scores of two groups Mann- Whitney U test was conducted after seeing that there was no statistically significant difference between pretest mean scores of control and experimental groups (Mann-Whitney $U=446.000$; $p=.959>0.05)$. The finding was presented in Table 7 . 
Table 7. The Pretest and Posttest Scores of Groups Mann Whitney

\begin{tabular}{|c|c|c|c|c|c|c|}
\hline & \multicolumn{2}{|c|}{ Control } & \multicolumn{3}{|c|}{ Experimental } & \multirow[b]{2}{*}{$\mathbf{p}$} \\
\hline & $X$ & $\overline{\bar{S} s}$ & $X$ & Ss & MW & \\
\hline Pretest & 183.516 & 37.003 & 179.690 & 21.706 & 446.000 & .959 \\
\hline Posttest & 196.807 & 42.874 & 215.552 & 39.087 & 318.500 & .053 \\
\hline
\end{tabular}

Table 7 shows that posttest scores of groups did not indicate significant difference (Mann Whitney $U=318.500 ; p=.053>0.05)$. It can be concluded that using mobile applications did not differ from using worksheets for gaining productive vocabulary knowledge.

\section{Discussion}

Both receptive and productive vocabulary knowledge is essential to linguistic ability. Hence, both of them were tried to be improved through CollocatApp and then measured through CAT and VKS in this study. The findings of CAT showed that the use of mobile application affected receptive vocabulary knowledge of language learners positively for a short term. On the other hand, use of worksheets did not have an effect on receptive vocabulary knowledge of the learners. When the groups were compared, it was seen that the participants of the experimental group were more successful than the control group in the posttests. This finding was parallel with other research studies that use different features and tools of mobile technology such as SMS, mobile applications, and other mobile systems generated by researchers. Studies of Liu and Chen (2014), Başoğlu and Akdemir (2010), Rahimi and Miri (2014), Wu (2015), Zhang et al. (2011), Lu (2008) and Saran et al. (2012) also showed that experimental groups using mobile technologies got higher scores in the posttest than control groups who studied vocabulary based on paper.

Taken together, it was concluded that using mobile technologies was an effective way of learning vocabulary receptively but for only short term memory as the same affect was not found in delayed test. The findings showed that there were significant differences between the posttest and delayed test in a negative way in both groups. Reinforcement in terms of continual review is required in order to store the vocabulary in long term memory (Bornstein, n.d.). However, there was no use of mobile application and worksheets during 3 weeks, and accordingly there was no repetition important for vocabulary learning. Thus, there were problems in retention of learned collocations for both groups. When the effect size of groups was compared it was observed that forgetting was less in the control group than experimental group. The findings of this study about the retention of words were parallel with the findings of some studies, while it was vice versa for some other studies. For example, the studies of Zhang et al. (2011) and $\mathrm{Lu}$ (2008) showed that mobile technology was effective in learning vocabulary but not in retention of these words. On the other hand, in the study of Alemi et al. (2012) experimental group using m-technology achieved higher scores in the delayed test than control group while there was no significant difference between two groups in terms of posttest scores. Saran et al. (2012) also concluded that mobile technology was effective in the retention of words. However, the experimental 
group of that study achieved more than control group in the posttest. Although the contents and activities of mobile application given to experimental group and worksheets of the control group were the same, experimental group achieved more for receptive vocabulary knowledge for short term memory. The reason for this may be due to the characteristics of mobile application which are visuality, feasibility, interactivity and immediate feedback. Technology provides many auditory and visual elements to learners. Besides, CollocatApp has the features of input, interaction and feedback which are three main benefits of mobile technologies (Jee, 2011). Another feature of CollocatApp that differentiated it from worksheets was its feasibility. The students may not want to carry their worksheets continuously with them, but it is clear that in the era of technology, especially the young carry their smartphones with them. Thus, they have the opportunity of studying anywhere at any time. This place may be a queue or a bus where learners can deal with their m-technology to pass the time. As the activities on mobile applications are like games, or many applications include games this boring time gets funny. Another feature of CollocatApp was interactivity which enabled learners to give feedback to the other users. This feature enabled students to see other users' sentences, which is important in terms of seeing many linguistic examples. The users commented on those sentences about if they were wrong or true, which requires a more advanced level of learning. Lastly, the app involves automatic feedback in the first three parts which provided immediate feedback to the learners. Immediate feedback is important as it enhances learning and corrects the first wrong responses (Epstein et al., 2002). Titova and Samoylenko (2017) also found that immediate feedback which was given through PeLE (a mobile-testing system) was quite supportive and encouraging in terms of learning. On the contrary to the findings of RVK, the groups did not show a significant difference in PVK. The posttest of the experimental group was significantly higher than its pretest whereas there was no difference in both tests in the control group. The participants using mobile applications achieved higher scores in their posttest. On the other hand, control group using papers did not show improvement in their posttest. Despite this finding, both groups were statistically the same in posttests when they were compared.

When the results of CAT and VKS were commented together, it was concluded that use of mobile application was more effective for RVK for a limited time. The CollocatApp included activities both for receptive and productive vocabulary knowledge. Nevertheless, PVK and RVK analysis showed significant difference for the experimental group, while this difference was not seen in the control group. The reason can be that the users of mobile application may focus on more receptive activities. However, as there was no record of which activities the learners dealt with more, it was not right to defend this prediction. Moreover, gaining productive vocabulary knowledge may take more time than gaining receptive vocabulary knowledge. Webb (2008) mentions four problems about measuring RVK and PVK by addressing Vocabulary Levels Test (VLT) used for measuring receptive vocabulary knowledge and Productive Vocabulary Levels Test (PVLT) used for productive vocabulary knowledge. The first one is that while VLT has $17 \%$ chance of guessing the word correctly, in PVLT guessing is not possible or there has been very little chance, which leads that the scores in VLT may be higher than PVLT. The second problem is about the format of the tests; VLT is in the format of recognition while PVLT is a recall test. Thirdly, whereas it is enough to know the meaning and form of the word for passing VLT, learners should also know the grammatical functions of the words in order to pass PVLT. Finally, PVLT can also be regarded as a test that measures receptive vocabulary knowledge. It is difficult to make a strict discrimination between the tests as the difference between receptive vocabulary knowledge and productive vocabulary knowledge is not clear. 


\section{Conclusions}

This study which aimed to determine the effectiveness of mobile applications in collocation learning of EFL learners founded that there was a significant difference between the experimental group and control group in terms of receptive vocabulary knowledge. However, this effect was not observed in retention test. The possible reasons behind these findings was discussed based on the literature in the section above. It was concluded that some findings of this study supported the literature while the others contradicted with it.

Research shows that MALL is a promising and fertile field (Bárcena et al., 2015). Thus, it is suggested that this promising field should be discovered more due to both its benefits to education system and the lack of the studies in the area. There are some studies on the role of m-learning in vocabulary knowledge and motivation. However, most of these studies used SMS, MMS or e-mail. Mobil applications are different from these systems in terms of involving more audio and visual features and games. Thus, it is suggested that the effect and role of m-learning on language learning process are investigated also through mobile applications which are very popular in recent years. This study adopted quantitative methodology and so qualitative and mixed method studies can be conducted in order to get opinions about the results that are obtained in quantitative studies.

\section{Ethics Committee Approval}

The authors confirm that the study does not need ethics committee approval according to the research integrity rules in their country. (Date of Confirmation: March 23, 2020)

\section{Acknowledgements}

This study is a part of the first author's PhD thesis titled "The role of Mobile-Assisted Language Learning (MALL) in vocabulary knowledge, learner autonomy and motivation of prospective English language teachers" supervised by the second author and co-supervised by the third author.

\section{References}

Ağca, R. K., \& Özdemir, S. (2013). Foreign language vocabulary learning with mobile technologies. $\begin{array}{lllll}\text { Procedia-Social and } & \text { Behavioral }\end{array}$ https//doi.org/10.1016/j.sbspro.2013.06.147

Alemi, M., Sarab, M., \& Lari, Z. (2012). Successful learning of academic word list via MALL: Mobile Assisted Language Learning. International Education Studies, 5(6), 99-109. https//doi.org/: $\underline{10.5539 / \text { ies.v5n6p99 }}$

Azar, A. S., \& Nasiri, H. (2014). Learners' attitudes toward the effectiveness of Mobile Assisted Language Learning (MALL) in L2 listening comprehension. Procedia-Social Behavioral Sciences, 98, 1836-1843. https//doi.org/10.1016/j.sbspro.2014.03.613

Bárcena, E. et al. (2015). State of the art of language learning design using mobile technology: Sample apps and some critical reflection. In F. Helm, L. Bradley, M. Guarda, \& S. Thouësny (Eds.), Critical CALL - Proceedings of the 2015 EUROCALL Conference, (pp. 36-43). Dublin: Researchpublishing.net. https//doi.org/10.14705/rpnet.2015.000307 
Başoğlu, E., \& Akdemir, O. (2010). A comparison of undergraduate students' English vocabulary learning: Using mobile phones and flash cards. Turkish Online Journal of Educational Technology, 9(3), 1-7. Retrieved from https://eric.ed.gov/?id=EJ898010

Bornstein, A. (n.d.). Memorizing vocabulary and languages. VideoJug, Retrieved from http://www.videojug.com/interview/memorizing-vocabulary-and-languages.

Bruton, A. (2009). The Vocabulary Knowledge Scale: A critical analysis. Language Assessment Quarterly, 6, 288-297. $\quad$ Retrieved from https://www.tandfonline.com/doi/abs/10.1080/15434300902801909?journalCode=hlaq20

Chen, C. M., \& Chung, C. J. (2008). Personalized mobile English vocabulary learning system based on item response theory and learning memory cycle. Computers \& Education, 51(2), 624-645. https//doi.org/10.1016/j.compedu.2007.06.011

Cohen, J. (1960). A coefficient of agreement for nominal scales. Educational and Psychological Measurement, 20(1), 37-46. https//doi.org/10.1177/001316446002000104

Çavuş, N., \& Ibrahim, D. (2009). m-Learning: An experiment in using SMS to support learning new English language words. British Journal of Educational Technology, 40(1), 78-91. https//doi.org/10.1111/j.14678535.2007.00801.x

Deng, H., \& Shao, Y. (2011). Self-directed English vocabulary learning with a mobile application in everyday context. 10th World Conference on Mobile and Contextual Learning: mLearn 2011 Conference Proceedings, China, 24-31.

Epstein, M. L., Lazarus, A. D., Calvano, T. B., Matthews, K. A., Hendel, R. A., Epstein, B. B., \& Brosvic, G. M. (2002). Immediate feedback assessment technique promotes learning and corrects inaccurate first responses. The Psychological Record, 52(2), 187-201. Retrieved from http://opensiuc.lib.siu.edu/tpr/vol52/iss2/5/

Hayati, A., Jalilifar, A., \& Mashhadi, A. (2013). Using Short Message Service (SMS) to teach English idioms to EFL students. British Journal of Educational Technology, 44(1), 66-81. https//doi.org/ 10.1111/j.1467-8535.2011.01260.x

Hu, Z. (2013). Vocabulary learning assisted by mobile phones: Perceptions of Chinese adult learners. Journal of Cambridge Studies, 8(1), 139 - 154. https//doi.org/10.17863/CAM.1468.

Huang, Y-M., Huang, Y-M., Huang, S-H. \& Lin Y-T. (2012). A ubiquitous English vocabulary learning system: Evidence of active/passive attitudes vs. usefulness/ease-of-use. Computers \& Education, 58, 273-282. https//doi.org/10.1016/j.compedu.2011.08.008

Hubbard, P. (Ed.) (2009). Computer-assisted Language Learning: Critical Concepts in Linguistics, Volumes I-IV. London \& New York: Routledge.

Jee, M. J. (2011). Web 2.0 technology meets Mobile Assisted Language Learning. The IALLT Journal, 41(1), 161-175. Retrieved from http://ialltjournal.org/index.php/ialltjournal/article/view/127

Kukulska-Hulme, A., \& Shield, L. (2008). An overview of Mobile Assisted Language Learning: From content delivery to supported collaboration and interaction. ReCALL, 20(3), 271-289. https//doi.org/10.1017/S0958344008000335

Laufer, B., \& Goldstein, Z. (2004). Testing vocabulary knowledge: Size, strength, and computer adaptiveness. Language Learning, 54 (3), 399-436. https//doi.org/10.1111/j.00238333.2004.00260.x

Levy, M. (1997). CALL: Context and Conceptualisation. Oxford: Oxford University Press. 
Liu, P. L., \& Chen, C-J. (2014). Learning English through actions: A study of mobile-assisted language learning. Interactive Learning Environments, 23(2), 158-17. https//doi.org/ $\underline{10.1080 / 10494820.2014 .959976}$

Lu, M. (2008). Effectiveness of vocabulary learning via mobile phone. Journal of Computer Assisted Learning, 24(6), 515-525. https//doi.org/10.1111/j.1365-2729.2008.00289.x

McMillan, J. H., \& Schumacher, S. (2006). Research education: Evidence-based inquiry (6 $6^{\text {th }}$ ed.). USA: Pearson.

Miangah, T. M., \& Nezarat, A. (2012). Mobile-Assisted Language Learning. International Journal of Distributed and Parallel Systems, 3(1), 309-319. https//doi.org/10.5121/ijdps.2012.3126

Nino, A. (2015). Language learners' perceptions and experiences on the use of mobile applications for independent language learning in higher education. The IAFOR Journal of Education, Technologies \& Education Special Edition, 73-84. Retrieved from https://files.eric.ed.gov/fulltext/EJ1100623.pdf

O'Dell, F., \& McCarthy, M. (2008). English collocations in use: Advanced. Cambridge: Cambridge University Press.

O'Malley, C., Vavoula, G., Glew, J. P., Taylor, J., \& Sharples, M. (2005). Guidelines for learning/teaching/ tutoring in a mobile environment. Retrieved from http://www.mobilearn.org/download/results/public_deliverables/MOBIlearn_D4.1_Final.pdf

Polakova, P. \& Klimova, B. (2019). Mobile technology and generation z in the English language classroom: A preliminary study. Education Sciences, 9(3), 203-214. https://doi.org/10.3390/educsci9030203.

Rahimi, M., \& Miri, S. S. (2014). The impact of mobile dictionary use on language learning. Procedia - Social and Behavioral Sciences, 98, 1469-1474. https//doi.org/ 10.1016/j.sbspro.2014.03.567

Rezaei, A., Mai, N., \& Pesaranghader, A. (2014). The effect of mobile applications on English vocabulary acquisition. Jurnal Teknologi, 68(2), 73-83. https//doi.org/:10.11113/jt.v68.2912

Rodríguez-Arancón, P., Arús, J., \& Calle-Martínez, C. (2013). The use of current mobile applications in EFL. Procedia - Social and Behavioral Sciences, 103, 1189-1196. https//doi.org/10.1016/j.sbspro.2013.10.446.

Saran, M., Seferoglu, G., \& Cagiltay, K. (2012). Mobile language learning: Contribution of multimedia messages via mobile phones in consolidating vocabulary. The Asia-Pacific Education Researcher, 21(1), 181-190. Retrieved from https://web.b.ebscohost.com/abstract?direct=true \&profile=ehost $\&$ scope $=$ site \&authtype $=$ crawler $\&$ j $\underline{\mathrm{rnl}=01195646 \& \mathrm{AN}=74731081 \& \mathrm{~h}=\text { SGYe6I7Ov2ZoPQTvSBfJgTaGTQFdzsDWVayQExfAho8z0 }}$ \%2fr4T3FCs6EWXLRQIn2A2xuJVx2bk4MDQHfh1sEyVg\%3d\%3d\&crl=f\&resultNs=AdminWe bAuth\&resultLocal=ErrCrlNotAuth\&crlhashurl=login. aspx\%3fdirect\%3dtrue\%26profile\%3dehost \%26scope\%3dsite\%26authtype\%3dcrawler\%26jrnl\%3d01195646\%26AN\%3d74731081

Schmitt, N. (1998). Tracking the incremental acquisition of second language vocabulary: A longitudinal study. Language Learning, 48, 281-317. https//doi.org/10.1111/1467-9922.00042

Schmitt. N. (2014). Size and depth of vocabulary knowledge: What the research shows. Language Learning, 64 (4), 913-951. https//doi.org/10.1111/lang.12077

Seçer, İ. (2013). SPSS ve LISREL ile pratik veri analizi: Analiz ve raporlaştırma. Ankara: Anı Yayıncilik. 
Soleimani, E., İsmail, K., \& Mustaffa, R. (2014). The acceptance of Mobile Assisted Language Learning (MALL) among postgraduate ESL students in UKM. Procedia- Social and Behavioral Sciences, 118, 457-462. https//doi.org/:10.1016/j.sbspro.2014.02.062

Song, Y., \& Fox, R. (2005). Integrating m-technology into Web-based ESL vocabulary learning for working adult learners. Paper presented at Wireless and Mobile Technologies in Education, Tokushima.

Steel, C. (2012). Fitting learning into life: Language students' perspectives on benefits of using mobile apps. In Brown, M. Hartnett, M. and Stewart, T. (Eds.) Future challenges, sustainable futures (pp. 875-880). Proceedings Ascilite Welllington.

Stockwell, G. (2007). Vocabulary on the move: Investigating an intelligent mobile phone based vocabulary tutor. Computer-Assisted Language Learning, 20(4), 365-383. https//doi.org/10.1080/09588220701745817

Stockwell, G. (2010). Using mobile phones for vocabulary activities: Examining the effect of the platform. Language Learning \&Technology, 14(2), 95-110. Retrieved from https://eric.ed.gov/?id=EJ895975

Thornton, P., \& Houser, C. (2005). Using mobile phones in English education in Japan. Journal of Computer-assisted Learning, 21(3), 217-228. https//doi.org/10.1111/j.1365-2729.2005.00129.x

Titova, S., \& Samoylenko, O. (2017). An enquiry-based approach to develop language skills in mobilesupported classrooms. Journal of Language and Education, 3(3), 39-49. https//doi.org/10.17323/2411-7390-2017-3-3-39-49.

Webb, S. (2008). Receptive and productive vocabulary sizes of L2 learners. Studies in Second Language Acquisition, 30, 79-95. https//doi.org/10.1017/S0272263108080042

Wesche, M., \& Paribakht, S. T. (1996). Assessing second language vocabulary knowledge: Depth versus breadth. Canadian Modern Language Review, 53(1), 13-40.

Wu, Q. (2015). Pulling mobile assisted language learning (MALL) into the mainstream: MALL in broad practice. PLoS ONE, 10(5), 1-12. https//doi.org/10.1371/journal.pone.0128762.

Yurdagül, C. \& Öz, S. (2018). Attitudes towards mobile learning in English language education. Education Sciences, 8(3), 142-156. https//doi.org/10.3390/educsci8030142.

Zhang, H., Song, W., \& Burston, J. (2011). Reexamining the effectiveness of vocabulary learning via mobile phones. Turkish Online Journal of Educational Technology, 10(3), 203-214. Retrieved from https://files.eric.ed.gov/fulltext/EJ944968.pdf

\section{Appendix A- Statistical data related to development of Collocation Achievement Test (CAT)}

\begin{tabular}{lcc}
\hline Item & $\mathrm{P}$ & $\mathrm{R}$ \\
\hline $\mathrm{m} 02$ & .53 & .13 \\
$\mathrm{~m} 03$ & .22 & .94 \\
$\mathrm{~m} 05$ & .22 & .30
\end{tabular}




\begin{tabular}{|c|c|c|c|}
\hline m07 & .33 & & .75 \\
\hline $\mathrm{m} 08$ & .38 & & .43 \\
\hline m09 & .39 & & .60 \\
\hline $\mathrm{m} 10$ & .24 & & .49 \\
\hline $\mathrm{m} 11$ & .37 & & .78 \\
\hline $\mathrm{m} 12$ & .32 & & .29 \\
\hline $\mathrm{m} 17$ & .28 & & .41 \\
\hline $\mathrm{m} 18$ & .62 & & .13 \\
\hline $\mathrm{m} 19$ & .55 & & .25 \\
\hline $\mathrm{m} 20$ & .59 & & .27 \\
\hline $\mathrm{m} 21$ & .68 & & .52 \\
\hline $\mathrm{m} 22$ & .84 & & .14 \\
\hline $\mathrm{m} 23$ & .29 & & .08 \\
\hline $\mathrm{m} 24$ & .49 & & .46 \\
\hline $\mathrm{m} 25$ & .35 & & .63 \\
\hline $\mathrm{m} 26$ & .74 & & .17 \\
\hline $\mathrm{m} 27$ & .54 & & .46 \\
\hline $\mathrm{m} 28$ & .46 & & .41 \\
\hline $\mathrm{m} 29$ & .22 & & .52 \\
\hline m30 & .34 & & .73 \\
\hline $\mathrm{m} 31$ & .41 & .49 & \\
\hline $\mathrm{m} 32$ & .57 & .27 & \\
\hline $\mathrm{m} 33$ & .41 & .35 & \\
\hline m34 & .23 & .40 & \\
\hline $\mathrm{m} 35$ & .42 & .37 & \\
\hline m36 & .57 & .11 & \\
\hline $\mathrm{m} 37$ & .61 & .30 & \\
\hline $\mathrm{m} 38$ & .30 & .79 & \\
\hline $\mathrm{m} 40$ & .52 & .35 & \\
\hline
\end{tabular}




\section{Appendix B- The corpus}

\begin{tabular}{|c|c|c|}
\hline Types of collocations & Collocations & f \\
\hline \multirow[t]{15}{*}{ Verb+ Noun } & get the message & 582 \\
\hline & wreak havoc & 491 \\
\hline & take issue with & 410 \\
\hline & foot the bill & 271 \\
\hline & break the news & 220 \\
\hline & produce results & 208 \\
\hline & pass judgment on & 139 \\
\hline & disseminate information & 125 \\
\hline & withdraw troops & 123 \\
\hline & bring stability & 100 \\
\hline & face the facts & 91 \\
\hline & spell disaster & 76 \\
\hline & restore peace & 74 \\
\hline & give an account of & 60 \\
\hline & give reason & 50 \\
\hline \multirow{13}{*}{$\begin{array}{l}\text { Adjective+ Noun } \\
\text { concerted effort } 527\end{array}$} & infectious disease & \\
\hline & tough question & 316 \\
\hline & poor judgment & 249 \\
\hline & premature death & 247 \\
\hline & joint effort & 173 \\
\hline & physical exertion & 141 \\
\hline & empty promise & 123 \\
\hline & modest increase & 99 \\
\hline & considerable experience & 89 \\
\hline & vain hope & 71 \\
\hline & fragile peace & 63 \\
\hline & uneasy truce & 59 \\
\hline & opening gambit & 46 \\
\hline
\end{tabular}


bold experiment

sigh of relief

sense of purpose

glimmer of hope

flurry of activity

stroke of luck

burst of energy

clap of thunder

sense of achievement

thirst for knowledge
40

1011
561
288
172
160
122
90
64
63

\title{
Mobil destekli dil öğreniminin yabancı dil olarak İngilizce öğrenenlerin eşdizimsel sözcük öğrenimine etkisi
}

\begin{abstract}
$\ddot{O} \mathbf{z}$
$\mathrm{Bu}$ çalışmanın amacı, İngilizceyi yabancı dil olarak öğrenenlerin kelime bilgisi geliştirmelerinde mobil bir uygulamanın etkililiğini belirlemektir. Bu çalışma, deney ve kontrol gruplarından oluşan yarı deneysel araştırma yöntemini benimsemiş̧ir. Çalışmanın örneklemi, Türkiye'deki iki devlet üniversitesinde okuyan toplam 73 dil öğrencisinden oluşmaktadır. 14 hafta süren uygulama sırasında, deney grubu araştırmacılar tarafından geliştirilen bir mobil uygulama olan CollocatApp üzerinden 40 eşdizimsel sözcük öğrenmeye çalışırken, kontrol grubu aynı amaç için çalışma kağıtları kullanmıştır. Veriler, Wesche ve Paribakht (1996) tarafından geliştirilen Kelime Bilgisi Ölçeği (KBÖ) ve araştırmacılar tarafından geliştirilen Eşdizimsel sözcük Başarı Testi (EBT) ile toplanmıştır. Öğrencilerin alıcı kelime bilgisini ölçmek için EBT kullanılırken üretken kelime bilgisini test etmek için KBÖ kullanılmıştır. Bulgular, deney grubu ile kontrol grubu arasında son testteki alıcı kelime bilgisi açısından anlamlı bir fark olduğunu göstermiştir. Öte yandan, kalıcılık testlerinde gruplar arasında fark bulgulanmamıştır. Üretken kelime bilgisi açısından mobil uygulamaların ve çalışma kağıtlarının kullanımı arasında fark olmadığı görülmüştür. Böylece, mobil uygulamaların dil öğreniminde kullanımının sadece kısa süreli bellek için ve alıcı kelime bilgisini geliştirmede etkili bir yolu olduğu sonucuna varılmıştır.
\end{abstract}

Anahtar sözcükler: eşdizimsel sözcük, mobil destekli dil öğrenimi, kelime bilgisi, yabancı dil olarak İngilizce

\section{AUTHOR BIODATA}

Kübra OKUMUŞ DAĞDELER is an assistant professor in Sivas Cumhuriyet University. Her bachelor, MA and $\mathrm{PhD}$ degrees are in the field of English Language Teaching. Her main research interest is instructional technologies in foreign language teaching. 
Mustafa Yavuz KONCA graduated from Atatürk University in 1974. He received his PhD Degree in English Language and Literature in 1995. He served at Atatürk University as an assistant professor until 2018. He retired from Atatürk University in 2018. After his retirement, he continued his teaching career at Ağrı İbrahim Çeçen University. Currently, he is serving at this university as the Director of School of Foreign Languages.

Hakan DEMİÖZ is an assistant professor at the Department of English Language Teaching, Cumhuriyet University, Sivas, Turkey. He teaches literature and language teaching, language assessment and CALL courses at the department. His primary research interests mainly focus on L2 reading and writing, language assessment and teaching English through literature. 